\title{
Pain and Poppies: The Good, the Bad, and the Ugly of Opioid Analgesics
}

\author{
Tuan Trang, ${ }^{1,2}$ Ream Al-Hasani, ${ }^{3,4}$ Daniela Salvemini, ${ }^{5}$ Michael W. Salter, ${ }^{6}$ Howard Gutstein, ${ }^{7}$ and ${ }^{\oplus}$ Catherine M. Cahill ${ }^{8}$ \\ Departments of ${ }^{1}$ Comparative Biology and Experimental Medicine and ${ }^{2}$ Physiology and Pharmacology, Hotchkiss Brain Institute, University of Calgary, \\ Calgary, Alberta T2N 4N1, Canada, Departments of ${ }^{3}$ Anesthesiology and ${ }^{4}$ Anatomy-Neurobiology, Washington University School of Medicine, St. Louis, \\ Missouri 63110, ${ }^{5}$ Department of Pharmacological and Physiological Science, St. Louis University School of Medicine, St. Louis, Missouri 63104, \\ ${ }^{6}$ Neurosciences and Mental Health Program, Hospital for Sick Children, Toronto, Ontario M5G 0A4, Canada, ${ }^{7}$ MD Anderson Cancer Center, Houston, Texas \\ 77030, and ${ }^{8}$ Department of Anaesthesiology and Perioperative Care, University of California Irvine, Irvine, California 92697
}

Treating pain is one of the most difficult challenges in medicine and a key facet of disease management. The isolation of morphine by Friedrich Sertürner in 1804 added an essential pharmacological tool in the treatment of pain and spawned the discovery of a new class of drugs known collectively as opioid analgesics. Revered for their potent pain-relieving effects, even Morpheus the god of dreams could not have dreamt that his opium tincture would be both a gift and a burden to humankind. To date, morphine and other opioids remain essential analgesics for alleviating pain. However, their use is plagued by major side effects, such as analgesic tolerance (diminished pain-relieving effects), hyperalgesia (increased pain sensitivity), and drug dependence. This review highlights recent advances in understanding the key causes of these adverse effects and explores the effect of chronic pain on opioid reward.

\section{Significance Statement}

Chronic pain is pervasive and afflicts $>100$ million Americans. Treating pain in these individuals is notoriously difficult and often requires opioids, one of the most powerful and effective classes of drugs used for controlling pain. However, their use is plagued by major side effects, such as a loss of pain-relieving effects (analgesic tolerance), paradoxical pain (hyperalgesia), and addiction. Despite the potential side effects, opioids remain the pharmacological cornerstone of modern pain therapy. This review highlights recent breakthroughs in understanding the key causes of these adverse effects and explores the cellular control of opioid systems in reward and aversion. The findings will challenge traditional views of the good, the bad, and the ugly of opioids.

\section{Opioids and pain: scope of the problem}

It is estimated that $20-30 \%$ of Americans suffer from chronic pain, which is similar to that reported in Canada, Australia, and European countries (Blyth et al., 2001; Breivik et al., 2006; Johannes et al., 2010; Schopflocher et al., 2011). Equally striking is

\footnotetext{
Received July 16, 2015; revised Aug. 12, 2015; accepted Aug. 13, 2015.

This work is supported by Canadian Institutes of Health Research Grants MOP133523 (T.T.), MOP123298 (C.M.C.), and MOP123307 (M.W.S.), Natural Sciences and Engineering Research Council of Canada Grant RGPIN418299 (T.T.), the Rita Allen Foundation (T.T), the American Pain Society (T.T.), the Canada Research Chair Program (M.W.S.), the Anne and Max Tanenbaum Chair Program (M.W.S.), National Institutes of Health Grants R01 CA169519 (D.S.) and R21 DA040305 (D.S.), the National Institute on Drug Abuse Grant 1R01DA036680-01 (H.B.G.), Cancer Prevention and Research Institute of Texas Individual Investigator Research Award RP120408 (H.B.G.), and National Institute on Drug Abuse K99/R00 Pathway to Independence Award DA038725 (R.A.-H.). We thank Churmy Fan for assistance with figure illustrations.

Correspondence should be addressed to either of the following: Dr. Tuan Trang, Departments of Comparative Biology and Experimental Medicine, and Physiology and Pharmacology, Hotchkiss Brain Institute, University of Calgary, 3330 Hospital Drive, Calgary, Alberta T2N 4N1, Canada, E-mail: trangt@ucalgary.ca; or Dr. Catherine Cahill, Department of Anaesthesiology and Perioperative Care, University of California Irvine, Irvine, California 92697, E-mail: cmcahill@uci.edu.

DOI:10.1523/JNEUROSCI.2711-15.2015

Copyright $\odot 2015$ the authors $\quad 0270-6474 / 15 / 3513879-10 \$ 15.00 / 0$
}

that chronic pain is among the most common forms of chronic illness afflicting individuals younger than 60 years of age (O'Connor, 2009). Chronic pain is also a major cause of disability (Manchikanti et al., 2013), and it is the cardinal feature of a diverse spectrum of diseases, including arthritis, migraine, cancer, metabolic disorders, and neuropathies. Treating pain in these diseases is notoriously difficult and often requires opioids, the most potent class of drugs used for controlling pain. Opioids are particularly effective for treating acute moderate-to-severe pain after surgery or trauma, and they are quintessential drugs in a physician's pharmacological toolbox for managing chronic pain. In 2012, physicians in the United States wrote $>259$ million opioid prescriptions, which equates to one bottle of pills for every adult American (according to the Centers for Disease Control and Prevention). Consumption of prescription opioids is highest in the United States and Canada, and, in these countries, opioid use for managing pain continues to grow (Gomes et al., 2014). Long-term opioid exposure can result in the development of analgesic tolerance, the hallmark feature of which is a loss in pain- 
relieving effect. In an effort to overcome tolerance, current strategies involve the use of either higher (and more frequent) doses of opioids or switching to more potent opioid agonists. However, these strategies have limited success because tolerance often reestablishes over time, leaving patients without adequate pain control. The need for escalating amounts of opioids puts patients at risk of severe sides effects, including dependence and respiratory distress. In the United States, an estimated 2.1 million Americans suffer from opioid substance use disorders (according to the National Institute of Drug Abuse), and 44 deaths a day are attributed to opioid overdose (according to the Centers for Disease Control and Prevention). There is also a higher incidence of opioid prescription medication addiction that has led to an increase in heroin use and a nearly quadrupling of death rate from overdose between 2002 and 2013 (Okie, 2010). Prescription, diversion, and illicit use of opioid therapeutics have emerged as major societal concerns in recent years (Compton and Volkow, 2006; SAMHSA, 2011). Although the effect of opioid tolerance and dependence has gained considerable attention, the problem of opioid-induced hyperalgesia_ characterized by a paradoxical increase in pain sensitivity-is a less recognized consequence of opioid use. Despite the serious side effects that hinder long-term opioid use, there remains a strong reliance on this class of drugs for pain management. Therefore, it is imperative that we understand the underlying causes of these adverse effects to improve the utility of opioids in treating pain. In this review, we focused our efforts on critically evaluating the evidence that plateletderived growth factor receptor- $\beta$ (PDGFR- $\beta$ ), adenosine, and microglia are key cellular substrates in opioid analgesic tolerance, hyperalgesia, and neuropathic pain. We also present emerging evidence that chronic pain fundamentally alters reward circuitry, which has direct implications for the ability of opioids to alleviate the emotional component of pain and for their abuse potential. This article is a summary of topics covered in a mini-symposium. For a more comprehensive review of the subject, the reader is referred to other articles on this topic (Marchand et al., 2005; Beggs et al., 2012; Williams et al., 2013; Bourinet et al., 2014; Cahill et al., 2014; Grace et al., 2014; Fields and Margolis, 2015; Mélik Parsadaniantz et al., 2015).

\section{Opioid receptors, analgesia, and the CNS}

Opioids exert their effects through interaction with the superfamily of G-protein-coupled opioid receptors: $\mu, \delta$, and $\kappa$. All three receptor subtypes share extensive structural homology and couple to pertussis toxin-sensitive guanine nucleotide binding $\mathrm{G}_{\mathrm{i} / \mathrm{o}}$-proteins to inhibit adenylyl cyclase, activate potassium conductance, suppress calcium conductance, and inhibit neurotransmitter release (Feng et al., 2012). Opioid receptors are expressed throughout the CNS and PNS on key nodes within the pain pathway. In the CNS, opioid receptors are highly localized in subcortical regions of the brain (thalamus, periaqueductal gray, rostral ventromedial medulla, and locus ceruleus) from which descending pain-modulating pathways originate and in the dorsal horn region of the spinal cord, an area important for the relay of nociceptive input to the brain and a primary site of action for the analgesic effects of opioids (Fields, 2004; Fig. 1). In the spinal dorsal horn, opioid receptors are expressed primarily in laminae I and II, with the proportion of $\mu, \delta$, and $\kappa$ receptors comprising 70,20 , and 10\%, respectively (Gouardères et al., 1985; Morris and Herz, 1987; Stevens et al., 1991). These receptors are localized on presynaptic afferent fibers (Lamotte et al., 1976; Gamse et al., 1979), interneurons (Kemp et al., 1996), and postsynaptic projection neurons (Zieglgänsberger and Bayerl, 1976). Additional opioid-like receptors have been identified in the CNS, including the opioid receptor like-1 (ORL-1) receptor (Meunier et al., 1995; Fioravanti and Vanderah, 2008). Unlike classical opioid receptors, the ORL-1 receptor is insensitive to naloxone, a nonselective opioid receptor antagonist. Evidence suggests that opioids can also bind and activate the toll-like receptor 4 (TLR4), an innate immune pattern-recognition receptor (Hutchinson et al., 2010; Jacobsen et al., 2014). The importance of these nonclassical opioid receptors in the modulation of pain and in the negative effects associated with opioid use is beyond the scope of the current review (Largent-Milnes and Vanderah, 2010; Pasternak and Pan, 2013; Convertino et al., 2015).

\section{PDGFR- $\beta$ : novel role in opioid tolerance and neuropathic pain}

Opioid receptor activation triggers a complex cascade of signaling events. A major downstream consequence of $\mu$ receptor signaling is the activation of receptor tyrosine kinases, which are critically implicated in an array of cellular processes (Lemmon and Schlessinger, 2010). Wang et al. (2012) discovered recently in rats that chronic morphine treatment results in the activation of PDGFR- $\beta$, a receptor tyrosine kinase that is activated by $\mu$ receptors (Belcheva et al., 2001). Activation of the PDGFR- $\beta$ receptor, in turn, modulates $\mu$ receptor function (Belcheva et al., 2001). Key to their finding was that chronic morphine treatment induced PDGFR- $\beta$ phosphorylation, which was abrogated by imatinib, a Food and Drug Administration-approved inhibitor of PDGFR used clinically to treat cancer (Wang et al., 2012). Spinal or subcutaneous administration of imatinib significantly blocked the development of morphine analgesic tolerance and reversed established tolerance. Although imatinib prevented tolerance, when rats were challenged with morphine alone after repeated doses of morphine and imatinib, the animals were all tolerant to antinociceptive effects of morphine. This suggests that imatinib did not directly inhibit the processes that cause tolerance, but rather it bypassed these cellular adaptations in restoring the analgesic effects of morphine. The results indicate that imatinib could be effective as an adjuvant therapy to limit or reverse morphine analgesic tolerance.

The mechanism responsible for morphine-induced activation of the PDGFR- $\beta$ was identified to be dependent on the release of PDGF-B, a selective agonist of the PDGFR- $\beta$ receptor. Rodents treated with a PDGFR- $\beta-F c$ chimeric protein, which scavenges released PDGF-B, suppressed the development of morphine tolerance and restored analgesia in morphine tolerant rats, similar to the actions of imatinib. Conversely, administration of PDGF-B induced robust tolerance in opioid-naive animals, indicating that PDGFR- $\beta$ signaling is both necessary and sufficient to cause morphine analgesic tolerance. However, the importance of PDGF-B extends beyond morphine tolerance to include a role in neuropathic pain (pain arising from damage or dysfunction of the nervous system), which is often refractory to the analgesic effects of opioids. Donica et al. (2014) reported that morphine, when administered together with imatinib, reversed mechanical allodynia in nerve-injured rats, suggesting that this pathway may be responsible for dysfunction of opioid effects in neuropathic pain states. In contrast, mechanical allodynia was not affected when morphine or imatinib was administered alone (Donica et al., 2014). Collectively, these studies provide the first lines of evidence that PDGFR- $\beta$ signaling is a critical overlapping mechanism in the etiology of morphine tolerance and neuropathic pain. A major question arising from these studies is, what is the critical cell type(s) through which PDGFR- $\beta$ signaling gates mor- 

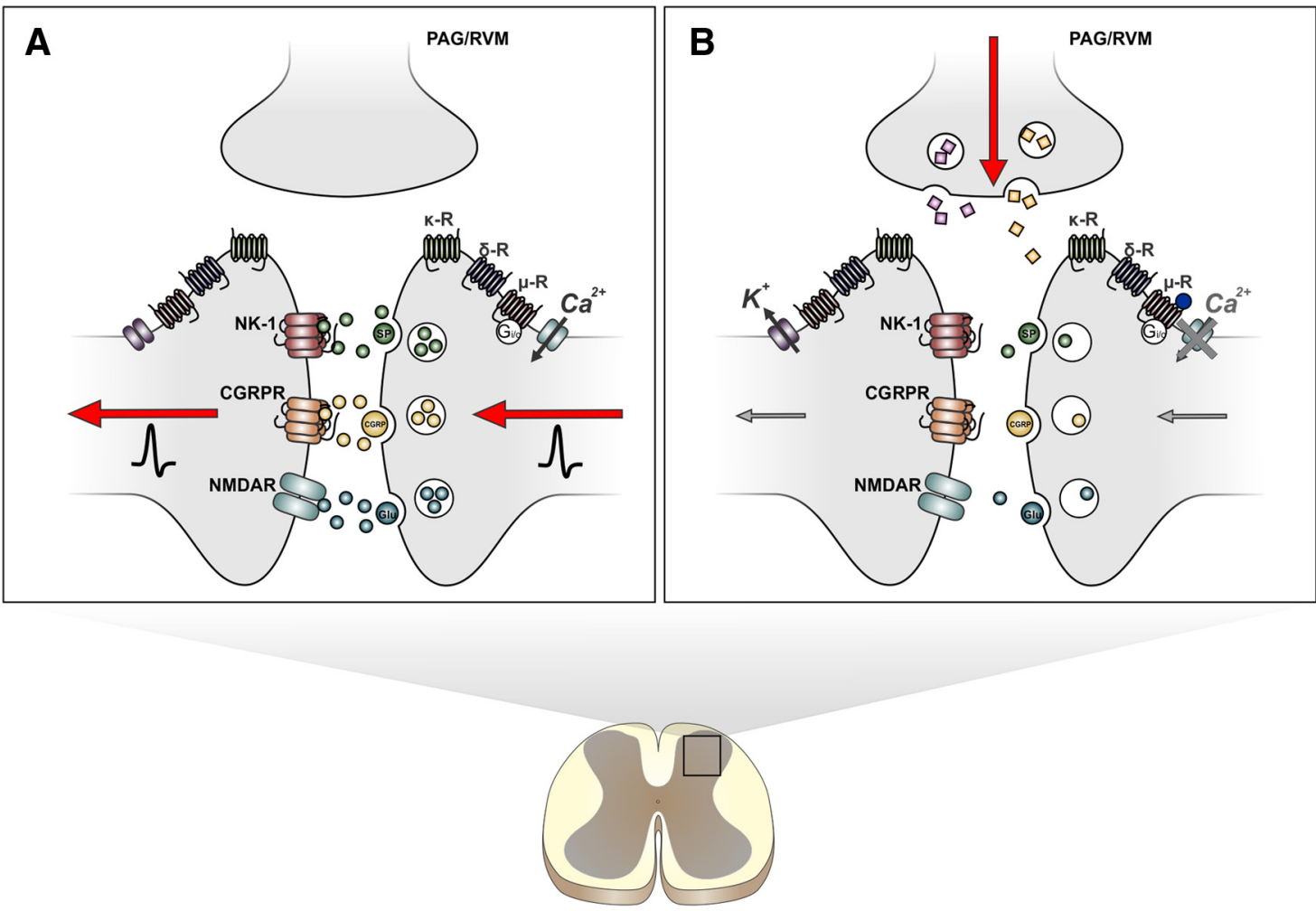

Figure 1. Spinal mechanisms of opioid analgesia. A, In the spinal dorsal horn, nociceptive signals encoded by action potentials trigger the release of nociceptive transmitters, such as substance $P(S P)$, calcitonin gene-related peptide (GRP), and L-glutamate (Glu). Second-order projection neurons then relay this information from the spinal cord to the brain, where the information is disseminated and decoded to produce the emotional and sensory experiences of pain. $\boldsymbol{B}$, Opioids produce their analgesic effects by inhibiting spinal nociceptive transmission. On presynaptic nerve terminals, opioids reduce cAMP signaling and suppress activity of voltage-gated calcium channels, which inhibits release of nociceptive transmitters. On postsynaptic neurons, opioids activate inward potassium channels to cause hyperpolarization of ascending projection neurons. Opioids also produce analgesia by activating descending inputs from the periaqueductal gray (PAG) and rostral ventromedial medulla (RVM), which are key components of the descending inhibitory pain pathways. In these supraspinal structures, opioid-mediated disinhibition of GABAergic interneurons leads to activation of monoamine-containing descending neurons that suppress nociceptive transmission in the spinal dorsal horn. (GRPR, Calcitonin gene-related peptide receptor; NK-1, neurokinin-1 receptor.

phine tolerance and neuropathic pain? Moreover, there are mechanistic similarities between the development of opioid tolerance and the occurrence of pain hypersensitivity associated with nerve injury, such as NMDA receptor phosphorylation and gliosis (Mao and Mayer, 2001; Wen et al., 2011). Whether there is overlap between these signaling cascades and PDGFR remains unresolved.

\section{Adenosine, adenosine receptors, and interactions with opioids}

Adenosine is an essential molecular building block for the prototypical energy source molecule ATP. However, adenosine in its own right is an important, biologically active molecule that regulates neuronal and non-neuronal function in the CNS and PNS. Released in response to trauma, seizure, inflammation, pain, and a host of other conditions, adenosine triggers compensatory homeostatic and neuromodulatory responses that protect against neuronal damage (Cunha, 2001). Extracellular adenosine can be derived through a series of catalytic steps. First, the cell surface ectonucleoside triphosphate diphosphohydrolase [cluster of differentiation (CD) 39] rapidly hydrolyzes ATP or ADP to AMP, which is then further broken down by ecto-5'-nucleotidase (CD73) to produce adenosine (Robson et al., 2006; Bonan, 2012). Another source of adenosine comes from intracellular pools released by ectonucleoside transporters (ENTs) expressed on neurons and glia (Bonan, 2012). The removal of extracellular adenosine is controlled by ENT uptake (when extracellular aden- osine concentration exceeds intracellular concentration), adenosine deaminase deamination, and intracellular phosphorylation by adenosine kinase (Blackburn and Kellems, 1996; Spychala et al., 1996; Thorn and Jarvis, 1996; King et al., 2006). It is generally accepted that adenosine kinase is the "upstream coordinator" of adenosine receptor (AR) signaling, which is mediated by the P1 family of G-protein-coupled receptors: $A_{1}, A_{2 A}, A_{2 B}$, and $A_{3} A R$ subtypes (Fredholm et al., 2005, 2011; Boison et al., 2010).

The first clues that adenosine may modulate pain and regulate opioid analgesia came from the demonstration that systemic administration of an adenosine analog is antinociceptive (Vapaatalo et al., 1975) and that methylxanthines (which block ARs) inhibits morphine analgesia (Ho et al., 1973a,b). Evidence soon emerged that the spinal cord is a key site of action for adenosine modulation of pain (Post, 1984) and that morphine administration in rats readily evokes the release of adenosine in the spinal cord (Sweeney et al., 1987). This release has also been reported in human subjects after intrathecal injection of fentanyl, a potent $\mu$ receptor agonist (Eisenach et al., 2004). It is now clear that spinal analgesia produced by adenosine or morphine administration depends critically on the adenosine receptor subtype A AR (Poon and Sawynok, 1998; Wu et al., 2005; Zhang et al., 2005). However, adenosine may be playing both the roles of "good cop" and "bad cop" because its activity has also been implicated in the unwanted side effects associated with chronic opioid use (Ahlijanian and Takemori, 1985; Contreras et al., 1990; Germany et al., 1990). For example, opioid withdrawal increases 
adenosine acting at $\mathrm{A}_{1} \mathrm{AR}$ in the ventral tegmental area (VTA) and substantia nigra, resulting in an inhibition of GABA release and thereby altering reward processing (Bonci and Williams, 1996; Shoji et al., 1999; Matsui et al., 2014). Chronic opioid administration can also decrease extracellular levels of adenosine and impair $A_{1}$ AR signaling in the brainstem (Nelson et al., 2009).

Attempts at targeting the adenosine system in search for better analgesics have focused on $\mathrm{A}_{1} \mathrm{AR}$ and $\mathrm{A}_{2} \mathrm{ARs}$ but with limited success because of negative side-effect profiles (Zylka, 2011; Boison, 2013). Other attempts aimed at increasing endogenous adenosine with recombinant ectonucleotidases (Sowa et al., 2010) or adenosine kinase inhibitors (Kowaluk et al., 2000) have also proved disappointing. Attention has now shifted to $\mathrm{A}_{3} \mathrm{AR}$ as a possible cellular target for developing novel analgesics (Little et al., 2015). A ARs are expressed throughout the CNS in neurons, astrocytes, and microglia, and their expression is upregulated by inflammatory cytokines (Abbracchio et al., 1997; Lopes et al., 2003). Importantly, these receptors are expressed in critical pain signaling areas such as the spinal dorsal horn and the rostral ventral medulla (Little et al., 2015), as well as in the reward pathways of the VTA and ventral striatum (D.S., unpublished observations). Small-molecule $\mathrm{A}_{3} \mathrm{AR}$ agonists that are potent, selective, and orally bioavailable (e.g., IB-MECA [N6-(3-iodobenzyl)adenosine-5'-N-methyl-uronamide $]$ and MRS5698 [(1S,2R, $3 S, 4 R, 5 S)$-4-[6-[[(3-chlorophenyl)methyl] amino]-2-[2-(3,4-difluorophenyl)ethynyl]-9H-purin-9-yl]-2,3-dihydroxy- $N$-methylbicyclo[3.1.0] hexane-1-carboxamide]) have been developed (Jacobson, 1998; Tosh et al., 2012) and tested in Phase II/III clinical trials for the treatment of cancer and various autoimmune disorders. These trials have reported favorable safety profiles (Fishman et al., 2002; Silverman et al., 2008; Stemmer et al., 2013). Moreover, a recent study by Little et al., (2015) found that selective $A_{3} A R$ agonists are potent, stand-alone agents that effectively attenuate chronic neuropathic pain without disrupting normal nociceptive processing. Tolerance to the analgesic effects of these novel $\mathrm{A}_{3} \mathrm{AR}$ agonists also did not develop, and their use did not produce inherent reward. Thus, $A_{3} A R$ appears to be a promising therapeutic target for developing novel analgesics that may complement, or be used as pharmacological substitutes of, traditional opioid therapy.

\section{Sex, opioids, pain... and microglia}

Neurons were considered the principal cell types targeted by opioid analgesics. This neuron-centric view was supported by evidence that repeated opioid exposure alters the fundamental properties of neurons and their circuits within the CNS and PNS and that this altered neuronal output is implicated causally in opioid tolerance, hyperalgesia, and dependence (Guitart and Nestler, 1989; Christie, 1991). However, the vast majority of cells within the nervous system are not neurons but rather glia (Banati, 2003). It is estimated that glia make up $70-90 \%$ of cells, with microglia comprising $\sim 10 \%$ of the total glial population in the adult CNS (Kreutzberg, 1996; Aguzzi et al., 2013; Kettenmann et al., 2013). Conventionally regarded as macrophages, microglia were relegated to being passive bystanders that subserve immune and supportive roles for neurons. This perception of microglia has changed radically in the past decade, and it is now apparent that microglia play an active and direct role in a variety of processes, including synaptic remodeling, neuronal excitability, and neurotransmission (Tremblay et al., 2010; Blank et al., 2014; Salter and Beggs, 2014). The role of microglia as cellular detectors and effectors of injury, infection, or disease has also gained considerable traction (Trang et al., 2012; Ji et al., 2013). In this re- spect, the importance of microglia in the sequelae of neuropathic pain is well established, and it is known that injury to a nerve instigates a stereotypical series of change in microglial morphology, gene expression, function, and number (Hanisch and Kettenmann, 2007; Kettenmann et al., 2011; Trang and Salter, 2012). These changes are also engaged by morphine; in response to chronic morphine treatment, microglia transform from a ramified ("resting") to amoeboid ("activated") state and upregulate expression of the cell-surface markers CD11b and ionized calcium-binding adaptor-1 (Ferrini et al., 2013; Schwarz et al., 2013; Mattioli et al., 2014). These phenotypic changes, triggered by opioid treatment or nerve injury, are the cellular and molecular signatures of microglial "activation.” Additional evidence that microglia are important opioid targets comes from reports that they express $\mu$ and $\kappa$ receptors (Chao et al., 1997; Mika et al., 2014). Activation of opioid receptors on microglia induces the release of a myriad of chemokines, cytokines, and neurotrophic factors (Coller and Hutchinson, 2012; Mélik Parsadaniantz et al., 2015). Treatments with nonspecific glial inhibitors (e.g., minocycline, fluorocitrate, or propentofylline) block the opioidinduced release of these signaling molecules and suppress the increase in microglial reactivity (Watkins and Maier, 2003; Cui et al., 2008; Horvath and DeLeo, 2009). The cellular effects of glial inhibitors translate into a reduction in morphine analgesic tolerance, an attenuation of the paradoxical increase in pain sensitivity, and a decrease in dependence (Horvath et al., 2010; Fukagawa et al., 2013). Glial inhibitors have also been found to alleviate pain hypersensitivity after peripheral nerve injury (Raghavendra et al., 2003; Guasti et al., 2009; Grace et al., 2014). Thus, the most parsimonious conclusion is that glia, in particular microglia, play an essential role in both neuropathic pain and the negative effects associated with long-term opioid use.

This conclusion, which is derived from experiments conducted almost exclusively on male rodents, has gained wide acceptance and is perpetuated by the discovery of an everincreasing number of microglial mechanisms being implicated in chronic pain. However, a study by Sorge et al. (2011) challenged the totality of such a conclusion as it relates to chronic pain mechanisms in male versus female mice. In this study, they reported that involvement of spinal TLR4 in mechanical allodynia was male specific. Because TLR4 in the CNS is expressed primarily on microglia, this initial observation hinted at the possible existence of a divergent microglial pain signaling mechanism being sexually dimorphic. In a more recent study, Sorge et al. (2015) demonstrated that intrathecal administration of glial inhibitors prevented and reversed mechanical allodynia caused by peripheral nerve injury in male, but not in female, mice. Allodynia in female mice was also resistant to selective ablation of spinal microglia by saporin toxin conjugated to macrophage antigen complex- 1 and occurred independent of purinergic $\mathrm{P} 2 \mathrm{X}_{4}$ receptor $\left(\mathrm{P} 2 \mathrm{X}_{4} \mathrm{R}\right)$-mediated release of brain-derived neurotrophic factor (BDNF), which is a core microglia pain signaling pathway identified previously in male rodents (see below) (Coull et al., 2005; Sorge et al., 2015). Together, these findings indicate that microglia are not sufficient for pain hypersensitivity in female mice. Instead, it appears that adaptive immune cells, likely T-lymphocytes, critically mediate pain hypersensitivity in female mice. This sexual dimorphism in mice is consistent with a clear gender bias in humans toward women being the majority of chronic pain patients (Mogil, 2012).

Although there is also evidence for sex differences in analgesic response to opioids and in susceptibility for opioid abuse in humans and rodents (Mogil, 2012; Lee and Ho, 2013), it remains to 


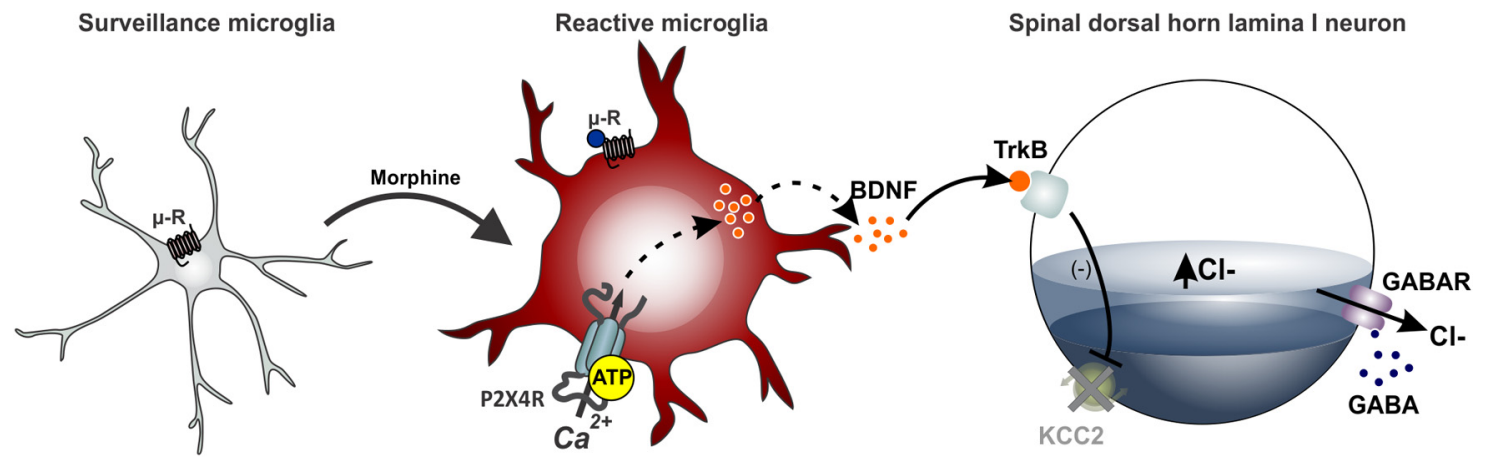

Figure 2. Microglial-mediated disruption of chloride homeostasis in spinal lamina I neurons gates morphine hyperalgesia. In response to chronic morphine treatment, microglia residing in the spinal cord adopt a reactive state characterized by $\mu$ receptor-dependent upregulation of $P 2 X_{4} R$ expression. Activation of $P 2 X_{4} R$ causes the release of BDNF, which signals to downregulate the potassium-chloride cotransport KCC2, resulting in a dysregulation of chloride homeostasis in spinal lamina I pain signaling neurons. The $P 2 \mathrm{X}_{4} \mathrm{R}-\mathrm{BDNF}-\mathrm{KCC} 2$ pathway is not only critical for the paradoxical hyperalgesic effect of morphine but also for pain hypersensitivity after peripheral nerve injury.

be shown whether these differences involve divergent microglial signaling mechanisms. Therefore, we will proceed to discuss a novel microglial signaling mechanism discovered to be essential in the paradoxical pain produced by morphine, with the explicit caveat that these discoveries were made using male rodent subjects. In this context, a recent study by Ferrini et al. (2013) examined the relationship between morphine analgesic tolerance and morphine-induced hyperalgesia; the prevailing view was that tolerance and hyperalgesia reflect a single underlying mechanism. In this study, the authors found that morphine acting on $\mu$ receptors drives increased expression of $\mathrm{P} 2 \mathrm{X}_{4} \mathrm{R}$ on microglia and that blocking $\mathrm{P} 2 \mathrm{X}_{4} \mathrm{R}$ or specifically ablating spinal microglia reversed morphine-induced hyperalgesia without affecting tolerance. Furthermore, morphine treatment caused a $\mathrm{P} 2 \mathrm{X}_{4} \mathrm{R}$-dependent release of BDNF from microglia: the release of BDNF signaled to downregulate the $\mathrm{Cl}^{-}$cotransporter KCC2 on spinal lamina I neurons, leading to a dysregulation of $\mathrm{Cl}^{-}$homeostasis (Fig. 2). Restoring $\mathrm{Cl}^{-}$homeostasis by genetically deleting BDNF from microglia reversed morphine-induced hyperalgesia but had no effect on analgesic tolerance. Collectively, these findings dissociate morphine-induced hyperalgesia from analgesic tolerance and suggest that interfering with key nodes in the microglia-toneuron $\mathrm{P} 2 \mathrm{X}_{4} \mathrm{R}-\mathrm{BDNF}-\mathrm{KCC} 2$ pathway suppresses hyperalgesia without affecting morphine analgesia. It is important to note that this pathway was first causally implicated in mechanical allodynia caused by peripheral nerve injury (Tsuda et al., 2003; Coull et al., 2005). Thus, the $\mathrm{P} 2 \mathrm{X}_{4} \mathrm{R}-\mathrm{BDNF}-\mathrm{KCC} 2$ pathway is a common microglial mechanism that underlies the hyperalgesic effects of morphine and neuropathic pain (Tsuda et al., 2003; Coull et al., 2005; Keller et al., 2007; Ulmann et al., 2008; Trang et al., 2009; Ferrini et al., 2013). Although this pathway is a major component of the functional alterations in the spinal dorsal horn that results in ongoing pain after chronic morphine treatment or peripheral nerve injury, it is one of several microglial mechanisms thought to contribute to these conditions (Watkins et al., 2001; Clark et al., 2007; Ji, 2010; Zhuo et al., 2011; Berta et al., 2014). How each of these mechanisms converges or diverges and whether sexual dimorphism has an effect on their relative importance has yet to be determined.

\section{Opioid reward and its modulation by chronic opioids and pain}

Opioids are potent analgesics that produce both positive and negative reinforcement. The positive reinforcing effects (euphoria, hedonism, or reward) resulting from opioid use are associ- ated strongly with their high potential for abuse, whereas the negative reinforcing effects of opioid use arise from the potent alleviation of the negative sensory and affective/emotional aspects of pain. A canonical neurotransmitter associated strongly with altered mood states and the positive and negative reinforcing effects of opioids is dopamine. The mesocorticolimbic system, which includes the VTA and the nucleus accumbens (NAc, part of the ventral striatum) is responsible for the expression of motivated behaviors, arousal, and reinforcement learning produced by natural (e.g., sex, food) and drug-rewarding stimuli, as well as aversion-based behaviors (Wise, 1989; Koob and Le Moal, 2005; Fields et al., 2007).

Dopaminergic neurons within the VTA are regulated by GABAergic tone via either intrinsic or synaptic input. Activation of opioid receptors expressed on intrinsic and synaptic projection GABAergic neurons causes an increase in dopamine release via disinhibition of the GABA tone. This opioid control of dopamine neurons is gated primarily by opioid receptors expressed on GABAergic terminals arising from the rostromedial tegmental nucleus (RMTg) rather than GABA intrinsic neurons or the NAc medium spiny neurons (Matsui et al., 2014). Additionally, separate GABA afferents are affected in the development of tolerance (RMTg) and withdrawal (NAc), whereas VTA GABAergic intrinsic neurons were not modulated by either state (Matsui et al., 2014). Nevertheless, the VTA is critical for opioid reward because rodents will self-administer intra-VTA morphine, and conditioned place preference to systemically administered morphine is blocked by intra-VTA administration of $\mu$ receptor antagonists (David et al., 2008; Mazei-Robison and Nestler, 2012; Fields and Margolis, 2015). These data together suggest that opioid receptors in the VTA are "sufficient" but not "necessary" for opioidinduced reward.

Recent studies suggest that VTA dopamine neurons are organized topographically according to output projection targets and that such organization may be relevant to their activation by appetitive and aversive stimuli (Lammel et al., 2012). Whether opioids modulate specific VTA dopaminergic output projections remains an important unresolved question. Similar to the VTA, the NAc shows topographical organization with hedonic and aversive "hot and cold spots" (McCutcheon et al., 2012; Berridge and Kringelbach, 2013). The rostrodorsal quadrant of the medial NAc shell contains a specialized opioid hedonic hotspot that mediates an increase in "liking" after $\mu$ receptor activation. In contrast, a distinct suppressive cold spot in the caudal half of the shell was identified in which opioid stimulation reduced sucrose pos- 


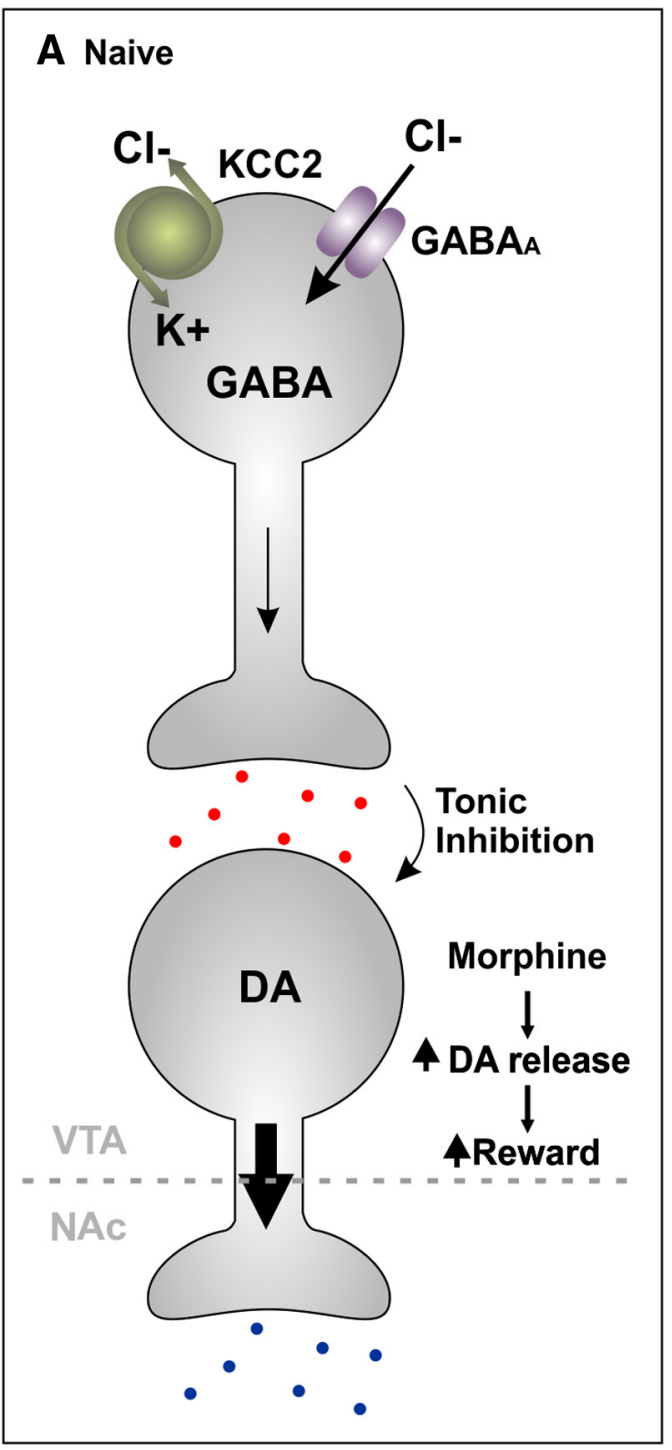

\section{B Neuropathic pain}
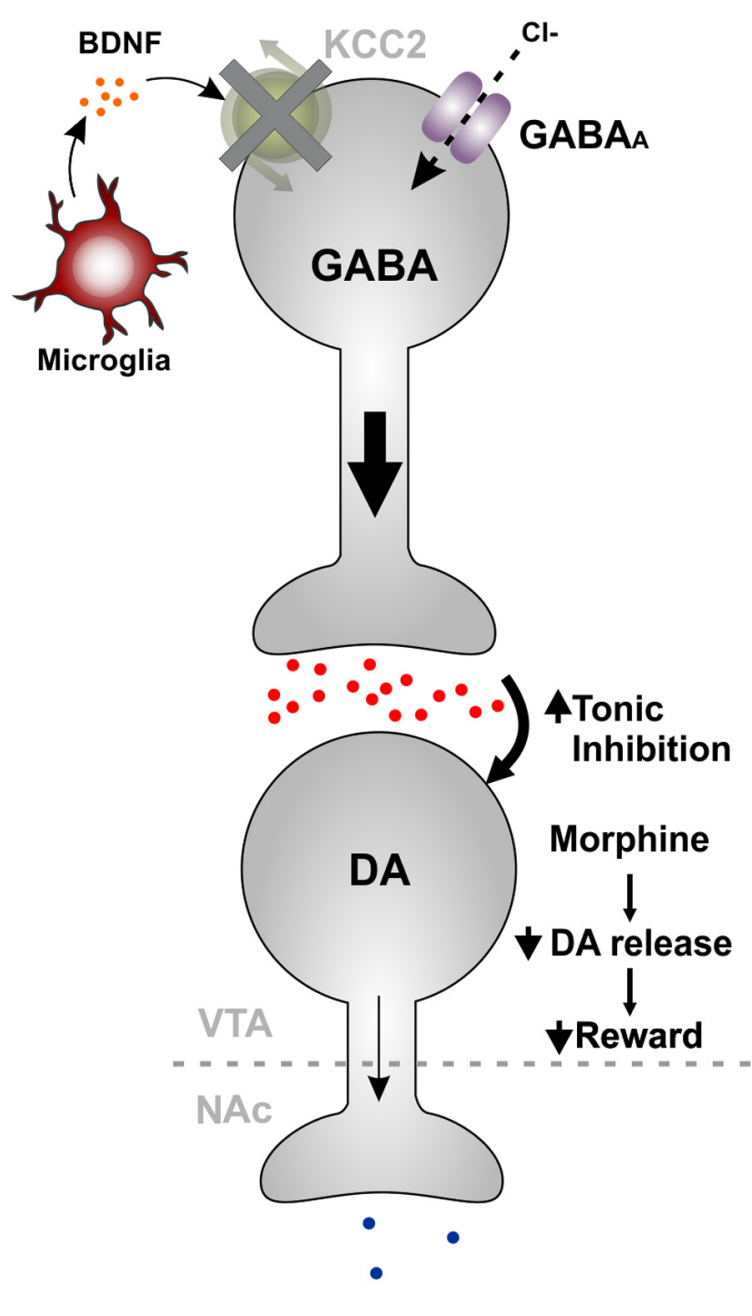

Figure 3. Model of microglial-mediated altered reward circuitry. As a consequence of chronic opioid exposure or chronic pain, microglial activation occurs in many areas of the CNS, including brain regions involved in reward such as the VTA. It is hypothesized that gliosis triggers a reorganization of reward circuitry such that microglia change $E_{G A B A}$ in GABAergic neurons within the VTA. $A$, In the naive state, these neurons tonically inhibit mesolimbic dopaminergic neurons projecting to the NAC. $B$, In chronic pain states, activated microglia release BDNF. This in turn causes disruption of $E_{G A B A}$ via downregulation of the $\mathrm{K}^{+} / \mathrm{Cl}^{-}$transporter $\mathrm{KCC} 2$ protein levels and activity. The loss of $\mathrm{KCC} 2$ causes a disruption of $\mathrm{Cl}^{-}$homeostasis in $\mathrm{GABAergic}$ neurons, resulting in these neurons being more depolarized. Consequently, activation of $\mathrm{AABA}_{\mathrm{A}}$ receptors on these $\mathrm{GABAergic} \mathrm{neurons} \mathrm{results} \mathrm{in} \mathrm{their} \mathrm{depolarization} \mathrm{rather} \mathrm{than} \mathrm{hyperpolarization} \mathrm{because} \mathrm{of} \mathrm{a} \mathrm{net} \mathrm{inward} \mathrm{anion}\left(\mathrm{Cl}^{-} / \mathrm{HCO}_{3}^{-}\right)$ current (that is normally outward). An increase in the excitability of GABAergic neurons results in an increase in GABA release and augmentation of the inhibitory tone on dopaminergic neurons, leading to less dopamine release in the NAc. DA, Dopamine.

itive liking reactions (Castro and Berridge, 2014). These results demonstrate the anatomical heterogeneity of the NAc and the importance of this region in opioid reward.

Reward produced by intra-VTA administration of opioids is blunted or absent after chronic opioid administration. This effect correlates with an increase in VTA GABAergic currents (Madhavan et al., 2010) and an increase in the frequency of spontaneous miniature IPSCs within the VTA dopaminergic neurons (Bonci and Williams, 1997). This is consistent with the report that electrically evoked VTA dopamine output to the NAc is decreased $24 \mathrm{~h}$ after cessation of chronic morphine (Mazei-Robison et al., 2011). Importantly, repeated drug exposure causes a decrease in the rewarding effect of the drug (reward tolerance), and this leads to an escalation of drug intake, as seen in humans (O'Brien, 1997). As noted previously, similarities exist between chronic opioid use and chronic pain. This is also true in the mesolimbic system. Similar to dependent states, morphine-stimulated dopamine release is attenuated in animals with chronic pain (Ozaki et al., 2002). Taylor et al. (2015b) replicated this finding and also reported that cocaine-induced, but not amphetamine-induced, dopamine release was attenuated in chronic pain animals. The impaired mesolimbic dopamine response in chronic pain is supported by a recent human functional magnetic resonance imaging study that found dramatically reduced reward-stimulated activity in the VTA of fibromyalgia patients (Loggia et al., 2014).

Although the mechanisms underlying the neuronal plastic changes associated with the development and the progression of drug addiction remain unknown, BDNF is implicated in incentive motivation that drives drug-seeking behavior. BDNF is a critical modulator of VTA dopamine neuronal activity in opioiddependent animals (Vargas-Perez et al., 2009, 2014; Koo et al., 2012). Furthermore, intra-VTA BDNF can produce an opioid- 
dependent-like state in naive animals (Laviolette and van der Kooy, 2001; Laviolette et al., 2002, 2004; Vargas-Perez et al., 2009, 2014). BDNF can cause $\mathrm{GABA}_{\mathrm{A}}$ function in VTA GABAergic interneurons to shift from inhibition to excitation (Fig. 3). There is evidence in other systems that BDNF can change GABAergic excitability via downregulation of KCC2 (Coull et al., 2005; Ferrini et al., 2013; Gagnon et al., 2013; Ting-A-Kee et al., 2013). Like other areas of the brain, downregulation of KCC2 in VTA $\mathrm{GABA}_{\mathrm{A}}$-expressing neurons results in an increase in their excitability. It was identified recently that both chronic pain and chronic administration of morphine causes a loss in the expression of KCC2 in VTA GABAergic neurons that results in a greater tonic inhibition on dopamine neurons (Taylor et al., 2015a,b). The mechanism of how chronic administration of opioids or chronic pain modulates reward circuitry within the VTA remains unresolved, although recent evidence demonstrates that microglial activation contributes to changes in opioid reward (Taylor et al., 2015a,b). Chronic morphine administration results in significant gliosis in the VTA and NAc (Narita et al., 2006; Hutchinson et al., 2009; Schwarz et al., 2013). Similarly, chronic pain in the absence of opioid medication use also causes microglial activation in reward circuitry (Taylor et al., 2015b). Inhibitors of both $\mathrm{BDNF}$ and microglia recover the loss of KCC2 function and restores morphine- and cocaine-evoked dopamine release. The functional behavioral consequence of this change in VTA GABAergic tone was evidenced by the loss of reward-related behaviors dependent on mesolimbic dopamine release in the NAc. Hence, intra-NAc cocaine and intra-VTA opioid conditioned place preference was blunted in chronic pain animals. Again, microglial inhibitors recovered reward in chronic pain animals but had no effect in pain-naive animals. Together, such findings suggest that microglial activation results in dysfunction of reward reliant on mesolimbic dopamine during ongoing chronic pain or opioid-dependent states. How microglia become activated in the brain after a peripheral nerve injury remains unresolved, and it is unknown whether any of these effects are reversible.

\section{Summary}

In 1680, Thomas Sydenham espoused that "Among the remedies which it has pleased almighty God to give to man to relieve his sufferings, none is so universal and so efficacious as opium." Indeed, the potent pain-relieving effects of opioids are unmatched, but it is now understood that along with the "good" can come the "bad": analgesic tolerance, hyperalgesia, dependence, and reward are recognized as potential adverse consequences of opioid use. Attempts to negate the adverse effects of opioids and provide relief to those in pain have been directed mostly at neuronal targets but with only limited success. These strategies were predicated on the misconception that neurons are the sole and principal targets of opioid action. On the contrary, converging lines of evidence indicate that opioids engage a complex constellation of cellular and molecular processes, through which a diversity of cell types interact to produce the negative effects associated with opioid use. Glia-neuron interactions are key to establishing and maintaining altered responsiveness of the CNS to long-term opioid treatment, and, in particular, it is the influence of microglia that is critical. The conceptual shift from microglia as passive bystanders to active effectors of opioid analgesia is a major breakthrough that has reoriented the search for new therapeutic targets. One potential target highlighted in this review is the microglia-to-neuron $\mathrm{P}_{2} \mathrm{X}_{4} \mathrm{R}-\mathrm{BDNF}-\mathrm{KCC} 2$ pathway, which serves an overlapping role in the pain hypersensitivity caused by repeated morphine treatment and by peripheral nerve injury.
This pathway is also important in altering reward circuitry in chronic pain states. Moreover, adenosine and PDGFR- $\beta$ signaling have emerged as a common mechanism in morphine tolerance and neuropathic pain. The commonalities in mechanisms between opioid tolerance, opioid-induced hyperalgesia, and neuropathic pain provide an exciting opportunity to bridge therapeutic strategies aimed at improving the utility of opioids for treating pain. However, the design of any therapeutic approach must take into account potential mechanistic differences between males and females given the recent evidence for sexual dimorphism in the role of microglia in neuropathic pain. The challenge, from the perspective of pain management, is to exploit this new knowledge to enhance the utility of opioids in treating chronic pain without stifling the potent analgesic properties of this important class of drugs.

\section{References}

Abbracchio MP, Rainaldi G, Giammarioli AM, Ceruti S, Brambilla R, Cattabeni F, Barbieri D, Franceschi C, Jacobson KA, Malorni W (1997) The A3 adenosine receptor mediates cell spreading, reorganization of actin cytoskeleton, and distribution of Bcl-XL: studies in human astroglioma cells. Biochem Biophys Res Commun 241:297-304. CrossRef Medline

Aguzzi A, Barres BA, Bennett ML (2013) Microglia: scapegoat, saboteur, or something else? Science 339:156-161. CrossRef Medline

Ahlijanian MK, Takemori AE (1985) Effects of (-)-N6-(R-phenylisopropyl)adenosine (PIA) and caffeine on nociception and morphine-induced analgesia, tolerance and dependence in mice. Eur J Pharmacol 112:171-179. CrossRef Medline

Banati RB (2003) Neuropathological imaging: in vivo detection of glial activation as a measure of disease and adaptive change in the brain. Br Med Bull 65:121-131. CrossRef Medline

Beggs S, Trang T, Salter MW (2012) P2X4R + microglia drive neuropathic pain. Nat Neurosci 15:1068-1073. CrossRef Medline

Belcheva MM, Szùcs M, Wang D, Sadee W, Coscia CJ (2001) mu-Opioid receptor-mediated ERK activation involves calmodulin-dependent epidermal growth factor receptor transactivation. J Biol Chem 276:3384733853. CrossRef Medline

Berridge KC, Kringelbach ML (2013) Neuroscience of affect: brain mechanisms of pleasure and displeasure. Curr Opin Neurobiol 23:294-303. CrossRef Medline

Berta T, Park CK, Xu ZZ, Xie RG, Liu T, Lü N, Liu YC, Ji RR (2014) Extracellular caspase- 6 drives murine inflammatory pain via microglial TNF- $\alpha$ secretion. J Clin Invest 124:1173-1186. CrossRef Medline

Blackburn MR, Kellems RE (1996) Regulation and function of adenosine deaminase in mice. Prog Nucleic Acid Res Mol Biol 55:195-226. CrossRef Medline

Blank T, Goldmann T, Prinz M (2014) Microglia fuel the learning brain. Trends Immunol 35:139-140. CrossRef Medline

Blyth FM, March LM, Brnabic AJ, Jorm LR, Williamson M, Cousins M) (2001) Chronic pain in Australia: a prevalence study. Pain 89:127-134. CrossRef Medline

Boison D (2013) Role of adenosine in status epilepticus: a potential new target? Epilepsia 54 [Suppl 6]:20-22.

Boison D, Chen JF, Fredholm BB (2010) Adenosine signaling and function in glial cells. Cell Death Differ 17:1071-1082. CrossRef Medline

Bonan CD (2012) Ectonucleotidases and nucleotide/nucleoside transporters as pharmacological targets for neurological disorders. CNS Neurol Disord Drug Targets 11:739-750. CrossRef Medline

Bonci A, Williams JT (1996) A common mechanism mediates long-term changes in synaptic transmission after chronic cocaine and morphine. Neuron 16:631-639. CrossRef Medline

Bonci A, Williams JT (1997) Increased probability of GABA release during withdrawal from morphine. J Neurosci 17:796-803. Medline

Bourinet E, Altier C, Hildebrand ME, Trang T, Salter MW, Zamponi GW (2014) Calcium-permeable ion channels in pain signaling. Physiol Rev 94:81-140. CrossRef Medline

Breivik H, Collett B, Ventafridda V, Cohen R, Gallacher D (2006) Survey of chronic pain in Europe: prevalence, impact on daily life, and treatment. Eur J Pain 10:287-333. CrossRef Medline

Cahill CM, Taylor AM, Cook C, Ong E, Morón JA, Evans CJ (2014) Does the 
kappa opioid receptor system contribute to pain aversion? Front Pharmacol 5:253. Medline

Castro DC, Berridge KC (2014) Opioid hedonic hotspot in nucleus accumbens shell: mu, delta, and kappa maps for enhancement of sweetness "liking" and "wanting." J Neurosci 34:4239-4250. CrossRef

Chao CC, Hu S, Shark KB, Sheng WS, Gekker G, Peterson PK (1997) Activation of mu opioid receptors inhibits microglial cell chemotaxis. J Pharmacol Exp Ther 281:998-1004. Medline

Christie MJ (1991) Mechanisms of opioid actions on neurons of the locus coeruleus. Prog Brain Res 88:197-205. CrossRef Medline

Clark AK, Yip PK, Grist J, Gentry C, Staniland AA, Marchand F, Dehvari M, Wotherspoon G, Winter J, Ullah J, Bevan S, Malcangio M (2007) Inhibition of spinal microglial cathepsin $\mathrm{S}$ for the reversal of neuropathic pain. Proc Natl Acad Sci U S A 104:10655-10660. CrossRef Medline

Coller JK, Hutchinson MR (2012) Implications of central immune signaling caused by drugs of abuse: mechanisms, mediators and new therapeutic approaches for prediction and treatment of drug dependence. Pharmacol Ther 134:219-245. CrossRef Medline

Compton WM, Volkow ND (2006) Abuse of prescription drugs and the risk of addiction. Drug Alcohol Depend 83 [Suppl 1]:S4-S7. CrossRef

Contreras E, Germany A, Villar M (1990) Effects of some adenosine analogs on morphine-induced analgesia and tolerance. Gen Pharmacol 21:763767. CrossRef Medline

Convertino M, Samoshkin A, Gauthier J, Gold MS, Maixner W, Dokholyan NV, Diatchenko L (2015) $\mu$-Opioid receptor 6-transmembrane isoform: A potential therapeutic target for new effective opioids. Prog Neuropsychopharmacol Biol Psychiatry 62:61-67. CrossRef Medline

Coull JA, Beggs S, Boudreau D, Boivin D, Tsuda M, Inoue K, Gravel C, Salter MW, De Koninck Y (2005) BDNF from microglia causes the shift in neuronal anion gradient underlying neuropathic pain. Nature 438:10171021. CrossRef Medline

Cui Y, Liao XX, Liu W, Guo RX, Wu ZZ, Zhao CM, Chen PX, Feng JQ (2008) A novel role of minocycline: attenuating morphine antinociceptive tolerance by inhibition of p38 MAPK in the activated spinal microglia. Brain Behav Immun 22:114-123. CrossRef Medline

Cunha RA (2001) Adenosine as a neuromodulator and as a homeostatic regulator in the nervous system: different roles, different sources and different receptors. Neurochem Int 38:107-125. CrossRef Medline

David V, Matifas A, Gavello-Baudy S, Decorte L, Kieffer BL, Cazala P (2008) Brain regional Fos expression elicited by the activation of mu- but not delta-opioid receptors of the ventral tegmental area: evidence for an implication of the ventral thalamus in opiate reward. Neuropsychopharmacology 33:1746-1759. CrossRef Medline

Donica CL, Cui Y, Shi S, Gutstein HB (2014) Platelet-derived growth factor receptor- $\beta$ antagonism restores morphine analgesic potency against neuropathic pain. PLoS One 9:e97105. CrossRef Medline

Eisenach JC, Hood DD, Curry R, Sawynok J, Yaksh TL, Li X (2004) Intrathecal but not intravenous opioids release adenosine from the spinal cord. J Pain 5:64-68. CrossRef Medline

Feng Y, He X, Yang Y, Chao D, Lazarus LH, Xia Y (2012) Current research on opioid receptor function. Curr Drug Targets 13:230-246. CrossRef Medline

Ferrini F, Trang T, Mattioli TA, Laffray S, Del'Guidice T, Lorenzo LE, Castonguay A, Doyon N, Zhang W, Godin AG, Mohr D, Beggs S, Vandal K, Beaulieu JM, Cahill CM, Salter MW, De Koninck Y (2013) Morphine hyperalgesia gated through microglia-mediated disruption of neuronal $\mathrm{Cl}^{-}$homeostasis. Nat Neurosci 16:183-192. CrossRef Medline

Fields H (2004) State-dependent opioid control of pain. Nat Rev Neurosci 5:565-575. CrossRef Medline

Fields HL, Margolis EB (2015) Understanding opioid reward. Trends Neurosci 38:217-225. CrossRef Medline

Fields HL, Hjelmstad GO, Margolis EB, Nicola SM (2007) Ventral tegmental area neurons in learned appetitive behavior and positive reinforcement. Annu Rev Neurosci 30:289-316. CrossRef Medline

Fioravanti B, Vanderah TW (2008) The ORL-1 receptor system: are there opportunities for antagonists in pain therapy? Curr Top Med Chem 8:1442-1451. CrossRef Medline

Fishman P, Bar-Yehuda S, Madi L, Cohn I (2002) A3 adenosine receptor as a target for cancer therapy. Anticancer Drugs 13:437-443. CrossRef Medline

Fredholm BB, Chen JF, Masino SA, Vaugeois JM (2005) Actions of adenosine at its receptors in the CNS: insights from knockouts and drugs. Annu Rev Pharmacol Toxicol 45:385-412. CrossRef Medline
Fredholm BB, IJzerman AP, Jacobson KA, Linden J, Müller CE (2011) International Union of Basic and Clinical Pharmacology. LXXXI. Nomenclature and classification of adenosine receptors-an update. Pharmacol Rev 63:1-34. CrossRef Medline

Fukagawa H, Koyama T, Kakuyama M, Fukuda K (2013) Microglial activation involved in morphine tolerance is not mediated by toll-like receptor 4. J Anesth 27:93-97. CrossRef Medline

Gagnon M, Bergeron MJ, Lavertu G, Castonguay A, Tripathy S, Bonin RP, Perez-Sanchez J, Boudreau D, Wang B, Dumas L, Valade I, Bachand K, Jacob-Wagner M, Tardif C, Kianicka I, Isenring P, Attardo G, Coull JA, De Koninck Y (2013) Chloride extrusion enhancers as novel therapeutics for neurological diseases. Nat Med 19:1524-1528. CrossRef Medline

Gamse R, Holzer P, Lembeck F (1979) Indirect evidence for presynaptic location of opiate receptors on chemosensitive primary sensory neurones. Naunyn Schmiedebergs Arch Pharmacol 308:281-285. CrossRef Medline Germany A, Villar M, Quijada L, Contreras E (1990) Influence of adenosine analogs on morphine tolerance and dependence in mice. Cell Mol Biol 36:409-414. Medline

Gomes T, Mamdani MM, Paterson JM, Dhalla IA, Juurlink DN (2014) Trends in high-dose opioid prescribing in Canada. Can Fam Physician 60:826-832. Medline

Gouardères C, Cros J, Quirion R (1985) Autoradiographic localization of $\mathrm{mu}$, delta and kappa opioid receptor binding sites in rat and guinea pig spinal cord. Neuropeptides 6:331-342. CrossRef Medline

Grace PM, Hutchinson MR, Maier SF, Watkins LR (2014) Pathological pain and the neuroimmune interface. Nat Rev Immunol 14:217-231. CrossRef Medline

Guasti L, Richardson D, Jhaveri M, Eldeeb K, Barrett D, Elphick MR, Alexander SP, Kendall D, Michael GJ, Chapman V (2009) Minocycline treatment inhibits microglial activation and alters spinal levels of endocannabinoids in a rat model of neuropathic pain. Mol Pain 5:35. CrossRef Medline

Guitart X, Nestler EJ (1989) Identification of morphine- and cyclic AMPregulated phosphoproteins (MARPPs) in the locus coeruleus and other regions of rat brain: regulation by acute and chronic morphine. J Neurosci 9:4371-4387. Medline

Hanisch UK, Kettenmann H (2007) Microglia: active sensor and versatile effector cells in the normal and pathologic brain. Nat Neurosci 10:13871394. CrossRef Medline

Ho IK, Loh HH, Way EL (1973a) Effects of cyclic 3', $5^{\prime}$-adenosine monophosphate on morphine tolerance and physical dependence. J Pharmacol Exp Ther 185:347-357. Medline

Ho IK, Loh HH, Way EL (1973b) Cyclic adenosine monophosphate antagonism of morphine analgesia. J Pharmacol Exp Ther 185:336-346. Medline

Horvath RJ, DeLeo JA (2009) Morphine enhances microglial migration through modulation of P2X4 receptor signaling. J Neurosci 29:998-1005. CrossRef Medline

Horvath RJ, Romero-Sandoval EA, De Leo JA (2010) Inhibition of microglial P2X4 receptors attenuates morphine tolerance, Ibal, GFAP and mu opioid receptor protein expression while enhancing perivascular microglial ED2. Pain 150:401-413. CrossRef Medline

Hutchinson MR, Lewis SS, Coats BD, Skyba DA, Crysdale NY, Berkelhammer DL, Brzeski A, Northcutt A, Vietz CM, Judd CM, Maier SF, Watkins LR, Johnson KW (2009) Reduction of opioid withdrawal and potentiation of acute opioid analgesia by systemic AV411 (ibudilast). Brain Behav Immun 23:240-250. CrossRef Medline

Hutchinson MR, Zhang Y, Shridhar M, Evans JH, Buchanan MM, Zhao TX, Slivka PF, Coats BD, Rezvani N, Wieseler J, Hughes TS, Landgraf KE, Chan S, Fong S, Phipps S, Falke JJ, Leinwand LA, Maier SF, Yin H, Rice KC, Watkins LR (2010) Evidence that opioids may have toll-like receptor 4 and MD-2 effects. Brain Behav Immun 24:83-95. CrossRef Medline

Jacobsen JH, Watkins LR, Hutchinson MR (2014) Discovery of a novel site of opioid action at the innate immune pattern-recognition receptor TLR4 and its role in addiction. Int Rev Neurobiol 118:129-163. CrossRef Medline

Jacobson KA (1998) Adenosine A3 receptors: novel ligands and paradoxical effects. Trends Pharmacol Sci 19:184-191. CrossRef Medline

Ji RR (2010) Targeting microglial purinergic signaling to improve morphine analgesia. Pain 150:377-378. CrossRef Medline

Ji RR, Berta T, Nedergaard M (2013) Glia and pain: is chronic pain a gliopathy? Pain 154 [Suppl 1]:S10-S28. CrossRef 
Johannes CB, Le TK, Zhou X, Johnston JA, Dworkin RH (2010) The prevalence of chronic pain in United States adults: results of an Internet-based survey. J Pain 11:1230-1239. CrossRef Medline

Keller AF, Beggs S, Salter MW, De Koninck Y (2007) Transformation of the output of spinal lamina I neurons after nerve injury and microglia stimulation underlying neuropathic pain. Mol Pain 3:27. CrossRef Medline

Kemp T, Spike RC, Watt C, Todd AJ (1996) The mu-opioid receptor (MOR1) is mainly restricted to neurons that do not contain GABA or glycine in the superficial dorsal horn of the rat spinal cord. Neuroscience 75:1231-1238. CrossRef Medline

Kettenmann H, Hanisch UK, Noda M, Verkhratsky A (2011) Physiology of microglia. Physiol Rev 91:461-553. CrossRef Medline

Kettenmann H, Kirchhoff F, Verkhratsky A (2013) Microglia: new roles for the synaptic stripper. Neuron 77:10-18. CrossRef Medline

King AE, Ackley MA, Cass CE, Young JD, Baldwin SA (2006) Nucleoside transporters: from scavengers to novel therapeutic targets. Trends Pharmacol Sci 27:416-425. CrossRef Medline

Koo JW, Mazei-Robison MS, Chaudhury D, Juarez B, LaPlant Q, Ferguson D, Feng J, Sun H, Scobie KN, Damez-Werno D, Crumiller M, Ohnishi YN, Ohnishi YH, Mouzon E, Dietz DM, Lobo MK, Neve RL, Russo SJ, Han MH, Nestler EJ (2012) BDNF is a negative modulator of morphine action. Science 338:124-128. CrossRef Medline

Koob GF, Le Moal M (2005) Plasticity of reward neurocircuitry and the "dark side" of drug addiction. Nat Neurosci 8:1442-1444. CrossRef Medline

KowalukEA, Mikusa J, Wismer CT, Zhu CZ, Schweitzer E, Lynch JJ, Lee CH, Jiang M, Bhagwat SS, Gomtsyan A, McKie J, Cox BF, Polakowski J, Reinhart G, Williams M, Jarvis MF (2000) ABT-702 (4-amino-5-(3-bromophenyl)-7-(6morpholino-pyridin- 3-yl)pyrido[2,3-d]pyrimidine), a novel orally effective adenosine kinase inhibitor with analgesic and anti-inflammatory properties. II. In vivo characterization in the rat. J Pharmacol Exp Ther 295:1165-1174. Medline

Kreutzberg GW (1996) Microglia: a sensor for pathological events in the CNS. Trends Neurosci 19:312-318. CrossRef Medline

Lammel S, Lim BK, Ran C, Huang KW, Betley MJ, Tye KM, Deisseroth K, Malenka RC (2012) Input-specific control of reward and aversion in the ventral tegmental area. Nature 491:212-217. CrossRef Medline

Lamotte C, Pert CB, Snyder SH (1976) Opiate receptor binding in primate spinal cord: distribution and changes after dorsal root section. Brain Res 112:407-412. CrossRef Medline

Largent-Milnes TM, Vanderah TW (2010) Recently patented and promising ORL-1 ligands: where have we been and where are we going? Expert Opin Ther Pat 20:291-305. CrossRef Medline

Laviolette SR, van der Kooy D (2001) GABA(A) receptors in the ventral tegmental area control bidirectional reward signalling between dopaminergic and non-dopaminergic neural motivational systems. Eur J Neurosci 13:1009-1015. CrossRef Medline

Laviolette SR, Nader K, van der Kooy D (2002) Motivational state determines the functional role of the mesolimbic dopamine system in the mediation of opiate reward processes. Behav Brain Res 129:17-29. CrossRef Medline

Laviolette SR, Gallegos RA, Henriksen SJ, van der Kooy D (2004) Opiate state controls bi-directional reward signaling via GABAA receptors in the ventral tegmental area. Nat Neurosci 7:160-169. CrossRef Medline

Lee CW, Ho IK (2013) Sex differences in opioid analgesia and addiction: interactions among opioid receptors and estrogen receptors. Mol Pain 9:45. CrossRef Medline

Lemmon MA, Schlessinger J (2010) Cell signaling by receptor tyrosine kinases. Cell 141:1117-1134. CrossRef Medline

Little JW, Ford A, Symons-Liguori AM, Chen Z, Janes K, Doyle T, Xie J, Luongo L, Tosh DK, Maione S, Bannister K, Dickenson AH, Vanderah TW, Porreca F, Jacobson KA, Salvemini D (2015) Endogenous adenosine A3 receptor activation selectively alleviates persistent pain states. Brain 138:28-35. CrossRef Medline

Loggia ML, Berna C, Kim J, Cahalan CM, Gollub RL, Wasan AD, Harris RE, Edwards RR, Napadow V (2014) Disrupted brain circuitry for painrelated reward/punishment in fibromyalgia. Arthritis Rheumatol 66:203212. CrossRef Medline

Lopes LV, Rebola N, Pinheiro PC, Richardson PJ, Oliveira CR, Cunha RA (2003) Adenosine A3 receptors are located in neurons of the rat hippocampus. Neuroreport 14:1645-1648. CrossRef Medline

Madhavan A, Bonci A, Whistler JL (2010) Opioid-Induced GABA potentiation after chronic morphine attenuates the rewarding effects of opioids in the ventral tegmental area. J Neurosci 30:14029-14035. CrossRef Medline

Manchikanti L, Helm Ii S, Singh V, Hirsch JA (2013) Accountable interventional pain management: a collaboration among practitioners, patients, payers, and government. Pain Physician 16:E635-E670. Medline

Mao J, Mayer DJ (2001) Spinal cord neuroplasticity following repeated opioid exposure and its relation to pathological pain. Ann NY Acad Sci 933:175-184. CrossRef Medline

Marchand F, Perretti M, McMahon SB (2005) Role of the immune system in chronic pain. Nat Rev Neurosci 6:521-532. CrossRef Medline

Matsui A, Jarvie BC, Robinson BG, Hentges ST, Williams JT (2014) Separate GABA afferents to dopamine neurons mediate acute action of opioids, development of tolerance, and expression of withdrawal. Neuron 82:1346-1356. CrossRef Medline

Mattioli TA, Leduc-Pessah H, Skelhorne-Gross G, Nicol CJ, Milne B, Trang T, Cahill CM (2014) Toll-like receptor 4 mutant and null mice retain morphine-induced tolerance, hyperalgesia, and physical dependence. PLoS One 9:e97361. CrossRef Medline

Mazei-Robison MS, Nestler EJ (2012) Opiate-induced molecular and cellular plasticity of ventral tegmental area and locus coeruleus catecholamine neurons. Cold Spring Harb Perspect Med 2:a012070. CrossRef Medline

Mazei-Robison MS, Koo JW, Friedman AK, Lansink CS, Robison AJ, Vinish M, Krishnan V, Kim S, Siuta MA, Galli A, Niswender KD, Appasani R, Horvath MC, Neve RL, Worley PF, Snyder SH, Hurd YL, Cheer JF, Han MH, Russo SJ, Nestler EJ (2011) Role for mTOR signaling and neuronal activity in morphine-induced adaptations in ventral tegmental area dopamine neurons. Neuron 72:977-990. CrossRef Medline

McCutcheon JE, Ebner SR, Loriaux AL, Roitman MF (2012) Encoding of aversion by dopamine and the nucleus accumbens. Front Neurosci 6:137. CrossRef Medline

Mélik Parsadaniantz S, Rivat C, Rostène W, Réaux-Le Goazigo A (2015) Opioid and chemokine receptor crosstalk: a promising target for pain therapy? Nat Rev Neurosci 16:69-78. CrossRef Medline

Meunier JC, Mollereau C, Toll L, Suaudeau C, Moisand C, Alvinerie P, Butour JL, Guillemot JC, Ferrara P, Monsarrat B (1995) Isolation and structure of the endogenous agonist of opioid receptor-like ORL1 receptor. Nature 377:532-535. CrossRef Medline

Mika J, Popiolek-Barczyk K, Rojewska E, Makuch W, Starowicz K, Przewlocka B (2014) Delta-opioid receptor analgesia is independent of microglial activation in a rat model of neuropathic pain. PLoS One 9:e104420. CrossRef Medline

Mogil JS (2012) Sex differences in pain and pain inhibition: multiple explanations of a controversial phenomenon. Nat Rev Neurosci 13:859-866. CrossRef Medline

Morris BJ, Herz A (1987) Distinct distribution of opioid receptor types in rat lumbar spinal cord. Naunyn Schmiedebergs Arch Pharmacol 336: 240-243. CrossRef Medline

Narita M, Yoshida T, Nakajima M, Narita M, Miyatake M, Takagi T, Yajima Y, Suzuki T (2006) Direct evidence for spinal cord microglia in the development of a neuropathic pain-like state in mice. J Neurochem 97: 1337-1348. CrossRef Medline

Nelson AM, Battersby AS, Baghdoyan HA, Lydic R (2009) Opioid-induced decreases in rat brain adenosine levels are reversed by inhibiting adenosine deaminase. Anesthesiology 111:1327-1333. CrossRef Medline

O’Brien CP (1997) A range of research-based pharmacotherapies for addiction. Science 278:66-70. CrossRef Medline

O'Connor AB (2009) Neuropathic pain: quality-of-life impact, costs and cost effectiveness of therapy. PharmacoEconomics 27:95-112. CrossRef Medline

Okie S (2010) A flood of opioids, a rising tide of deaths. N Engl J Med 363:1981-1985. CrossRef Medline

Ozaki S, Narita M, Narita M, Iino M, Sugita J, Matsumura Y, Suzuki T (2002) Suppression of the morphine-induced rewarding effect in the rat with neuropathic pain: implication of the reduction in mu-opioid receptor functions in the ventral tegmental area. J Neurochem 82:1192-1198. CrossRef Medline

Pasternak GW, Pan YX (2013) Mu opioids and their receptors: evolution of a concept. Pharmacol Rev 65:1257-1317. CrossRef Medline

Poon A, Sawynok J (1998) Antinociception by adenosine analogs and inhibitors of adenosine metabolism in an inflammatory thermal hyperalgesia model in the rat. Pain 74:235-245. CrossRef Medline

Post C (1984) Antinociceptive effects in mice after intrathecal injection of 
5'-N-ethylcarboxamide adenosine. Neurosci Lett 51:325-330. CrossRef Medline

Raghavendra V, Tanga F, Rutkowski MD, DeLeo JA (2003) Antihyperalgesic and morphine-sparing actions of propentofylline following peripheral nerve injury in rats: mechanistic implications of spinal glia and proinflammatory cytokines. Pain 104:655-664. CrossRef Medline

Robson SC, Sévigny J, Zimmermann H (2006) The E-NTPDase family of ectonucleotidases: Structure function relationships and pathophysiological significance. Purinergic Signal 2:409-430. CrossRef Medline

Salter MW, Beggs S (2014) Sublime microglia: expanding roles for the guardians of the CNS. Cell 158:15-24. CrossRef Medline

SAMHSA (2011) SAMHSA 2011: Substance Abuse and Mental Health Services Administration: 2011 national survey on drug use and health: summary of national findings and detailed tables. Rockville, MD: SAMHSA.

Schopflocher D, Taenzer P, Jovey R (2011) The prevalence of chronic pain in Canada. Pain Res Manag 16:445-450. Medline

Schwarz JM, Smith SH, Bilbo SD (2013) FACS analysis of neuronal-glial interactions in the nucleus accumbens following morphine administration. Psychopharmacology (Berl) 230:525-535. CrossRef Medline

Shoji Y, Delfs J, Williams JT (1999) Presynaptic inhibition of GABA(B)mediated synaptic potentials in the ventral tegmental area during morphine withdrawal. J Neurosci 19:2347-2355. Medline

Silverman MH, Strand V, Markovits D, Nahir M, Reitblat T, Molad Y, Rosner I, Rozenbaum M, Mader R, Adawi M, Caspi D, Tishler M, Langevitz P, Rubinow A, Friedman J, Green L, Tanay A, Ochaion A, Cohen S, Kerns WD, Cohn I, Fishman-Furman S, Farbstein M, Yehuda SB, Fishman P (2008) Clinical evidence for utilization of the A3 adenosine receptor as a target to treat rheumatoid arthritis: data from a phase II clinical trial. J Rheumatol 35:41-48. Medline

Sorge RE, LaCroix-Fralish ML, Tuttle AH, Sotocinal SG, Austin JS, Ritchie J, Chanda ML, Graham AC, Topham L, Beggs S, Salter MW, Mogil JS (2011) Spinal cord Toll-like receptor 4 mediates inflammatory and neuropathic hypersensitivity in male but not female mice. J Neurosci 31 : 15450-15454. CrossRef Medline

Sorge RE, Mapplebeck JC, Rosen S, Beggs S, Taves S, Alexander JK, Martin LJ, Austin JS, Sotocinal SG, Chen D, Yang M, Shi XQ, Huang H, Pillon NJ, Bilan PJ, Tu Y, Klip A, Ji RR, Zhang J, Salter MW, Mogil JS (2015) Different immune cells mediate mechanical pain hypersensitivity in male and female mice. Nat Neurosci 18:1081-1083. CrossRef Medline

Sowa NA, Voss MK, Zylka MJ (2010) Recombinant ecto-5'-nucleotidase (CD73) has long lasting antinociceptive effects that are dependent on adenosine A1 receptor activation. Mol Pain 6:20. CrossRef Medline

Spychala J, Datta NS, Takabayashi K, Datta M, Fox IH, Gribbin T, Mitchell BS (1996) Cloning of human adenosine kinase cDNA: sequence similarity to microbial ribokinases and fructokinases. Proc Natl Acad Sci U S A 93: 1232-1237. CrossRef Medline

Stemmer SM, Benjaminov O, Medalia G, Ciuraru NB, Silverman MH, BarYehuda S, Fishman S, Harpaz Z, Farbstein M, Cohen S, Patoka R, Singer B, Kerns WD, Fishman P (2013) CF102 for the treatment of hepatocellular carcinoma: a phase I/II, open-label, dose-escalation study. Oncologist 18:25-26. CrossRef Medline

Stevens CW, Lacey CB, Miller KE, Elde RP, Seybold VS (1991) Biochemical characterization and regional quantification of mu, delta and kappa opioid binding sites in rat spinal cord. Brain Res 550:77-85. CrossRef Medline

Sweeney MI, White TD, Jhamandas KH, Sawynok J (1987) Morphine releases endogenous adenosine from the spinal cord in vivo. Eur J Pharmacol 141:169-170. CrossRef Medline

Taylor AM, Castonguay A, Taylor AJ, Murphy NP, Ghogha A, Cook C, Xue L, Olmstead MC, De Koninck Y, Evans CJ, Cahill CM (2015a) Microglia disrupt mesolimbic reward circuitry in chronic pain. J Neurosci 35:84428450. CrossRef Medline

Taylor AM, Castonguay A, Ghogha A, Vayssiere P, Pradhan AA, Xue L, Mehrabani S, Wu J, Levitt P, Olmstead MC, De Koninck Y, Evans CJ, Cahill CM (2015b) Neuroimmune regulation of GABAergic neurons within the ventral tegmental area during withdrawal from chronic morphine. Neuropsychopharmacology. Advance online publication. Retrieved August 19, 2015. CrossRef Medline
Thorn JA, Jarvis SM (1996) Adenosine transporters. Gen Pharmacol 27: 613-620. CrossRef Medline

Ting-A-Kee R, Vargas-Perez H, Mabey JK, Shin SI, Steffensen SC, van der Kooy D (2013) Ventral tegmental area GABA neurons and opiate motivation. Psychopharmacology (Berl) 227:697-709. CrossRef Medline

Tosh DK, Deflorian F, Phan K, Gao ZG, Wan TC, Gizewski E, Auchampach JA, Jacobson KA (2012) Structure-guided design of A(3) adenosine receptorselective nucleosides: combination of 2-arylethynyl and bicyclo[3.1.0]hexane substitutions. J Med Chem 55:4847-4860. CrossRef Medline

Trang T, Salter MW (2012) P2X4 purinoceptor signaling in chronic pain. Purinergic Signal 8:621-628. CrossRef Medline

Trang T, Beggs S, Wan X, Salter MW (2009) P2X4-receptor-mediated synthesis and release of brain-derived neurotrophic factor in microglia is dependent on calcium and $\mathrm{p} 38$-mitogen-activated protein kinase activation. J Neurosci 29:3518-3528. CrossRef Medline

Trang T, Beggs S, Salter MW (2012) ATP receptors gate microglia signaling in neuropathic pain. Exp Neurol 234:354-361. CrossRef Medline

Tremblay MÈ, Lowery RL, Majewska AK (2010) Microglial interactions with synapses are modulated by visual experience. PLoS Biol 8:e1000527. CrossRef Medline

Tsuda M, Shigemoto-Mogami Y, Koizumi S, Mizokoshi A, Kohsaka S, Salter MW, Inoue K (2003) P2X4 receptors induced in spinal microglia gate tactile allodynia after nerve injury. Nature 424:778-783. CrossRef Medline

Ulmann L, Hatcher JP, Hughes JP, Chaumont S, Green PJ, Conquet F, Buell GN, Reeve AJ, Chessell IP, Rassendren F (2008) Up-regulation of P2X4 receptors in spinal microglia after peripheral nerve injury mediates $\mathrm{BDNF}$ release and neuropathic pain. J Neurosci 28:11263-11268. CrossRef Medline

Vapaatalo H, Onken D, Neuvonen PJ, Westermann E (1975) Stereospecificity in some central and circulatory effects of phenylisopropyladenosine (PIA). Arzneimittelforschung 25:407-410. Medline

Vargas-Perez H, Ting-A Kee R, Walton CH, Hansen DM, Razavi R, Clarke L, Bufalino MR, Allison DW, Steffensen SC, van der Kooy D (2009) Ventral tegmental area BDNF induces an opiate-dependent-like reward state in naive rats. Science 324:1732-1734. CrossRef Medline

Vargas-Perez H, Bahi A, Bufalino MR, Ting-A-Kee R, Maal-Bared G, Lam J, Fahmy A, Clarke L, Blanchard JK, Larsen BR, Steffensen S, Dreyer JL, van der Kooy D (2014) BDNF signaling in the VTA links the drugdependent state to drug withdrawal aversions. J Neurosci 34:7899-7909. CrossRef Medline

Wang Y, Barker K, Shi S, Diaz M, Mo B, Gutstein HB (2012) Blockade of PDGFR- $\beta$ activation eliminates morphine analgesic tolerance. Nat Med 18:385-387. CrossRef Medline

Watkins LR, Maier SF (2003) Glia: a novel drug discovery target for clinical pain. Nat Rev Drug Discov 2:973-985. CrossRef Medline

Watkins LR, Milligan ED, Maier SF (2001) Glial activation: a driving force for pathological pain. Trends Neurosci 24:450-455. CrossRef Medline

Wen YR, Tan PH, Cheng JK, Liu YC, Ji RR (2011) Microglia: a promising target for treating neuropathic and postoperative pain, and morphine tolerance. J Formos Med Assoc Taiwan Yi Zhi 110:487-494. CrossRef Medline

Williams JT, Ingram SL, Henderson G, Chavkin C, von Zastrow M, Schulz S, Koch T, Evans CJ, Christie MJ (2013) Regulation of $\mu$-opioid receptors: desensitization, phosphorylation, internalization, and tolerance. Pharmacol Rev 65:223-254. CrossRef Medline

Wise RA (1989) Opiate reward: sites and substrates. Neurosci Biobehav Rev 13:129-133. CrossRef Medline

Wu WP, Hao JX, Halldner L, Lövdahl C, DeLander GE, Wiesenfeld-Hallin Z, Fredholm BB, Xu XJ (2005) Increased nociceptive response in mice lacking the adenosine A1 receptor. Pain 113:395-404. CrossRef Medline

Zhang Y, Conklin DR, Li X, Eisenach JC (2005) Intrathecal morphine reduces allodynia after peripheral nerve injury in rats via activation of a spinal $\mathrm{Al}$ adenosine receptor. Anesthesiology 102:416-420. CrossRef Medline

Zhuo M, Wu G, Wu LJ (2011) Neuronal and microglial mechanisms of neuropathic pain. Mol Brain 4:31. CrossRef Medline

Zieglgänsberger W, Bayerl H (1976) The mechanism of inhibition of neuronal activity by opiates in the spinal cord of cat. Brain Res 115:111-128. CrossRef Medline

Zylka MJ (2011) Pain-relieving prospects for adenosine receptors and ectonucleotidases. Trends Mol Med 17:188-196. CrossRef Medline 